\title{
Protection of winter gardens constructions against corrosion caused by aqueous solution of hornbeam ash
}

\author{
Elena Yurchenko ${ }^{1}$, Alexander Volkov ${ }^{1, *}$, Konstantin Makarov ${ }^{1}$, Astkhik Kakosyan ${ }^{1}$, and \\ Vasilisa Yurchenko ${ }^{1}$ \\ ${ }^{1}$ Sochi State University, Plastunskaya street, 354003, Sochi, Russia
}

\begin{abstract}
The use of coarse-grained concrete (porosity 3-8\%) of class B 12.5 - 15 with water resistance of $\mathrm{W} 4$ and below is widespread in the village buildings in Russia and is associated with poor quality concrete production using manual labor. Since the mid-90s of the $20^{\text {th }}$ century, it has become fashionable to install cottages of greenhouses or winter gardens in the attic space, with fireplaces for heating and using wood ash as fertilizer for plants. According to the survey data, ash moistened during irrigation has bicarbonate alkalinity, slightly aggressive for concrete of this quality. Determination of the $\mathrm{pH}$ of the cement stone of the operated column structures was within the range of $\mathrm{pH}=11.8-12.6$, overlap $\mathrm{pH}=9.2-9.4$. The studied aqueous solution of hornbeam ash had a bicarbonate alkalinity of $0.81 \mathrm{mEq} / \mathrm{dm}^{3}$ and is a slightly aggressive medium for concrete of this quality. The paper provides measures to protect concrete with Penetron penetrating waterproofing.
\end{abstract}

\section{Introduction}

When examining a number of supporting structures of winter gardens arranged in the attic of cottages in Sochi, their capillary moisture, the presence of hairline cracks, a decrease in the design concrete class from B 20 to B 12.5 were revealed, as evidenced by the data [1]. The reason for this phenomenon is several, the first is the low quality of structures made of non-industrial concrete mix without plasticizers, the absence of vibration during installation, and its moistening during hardening. The second is the use of fertilizers in the form of wood ash in greenhouses and winter gardens, mainly hornbeam, which for such large-porous concrete is a slightly aggressive liquid medium when moistened during irrigation. The owners justified the use of this fertilizer with a high yield of $1 \mathrm{~kg}$ of dry wood, $4 \mathrm{~kg}$ of ash and known chemical properties. So according to [2], hardwood ash is in $\%$ for potassium oxide 8.4-13.3, phosphorus oxide 3.4-7.1, calcium oxide 36.3-75; according to Campbell, wood ash contains carbon in the range of $5-30 \%$, calcium $7-33 \%$, potassium $3-4 \%$, magnesium $1-2 \%$, manganese $0.3-1.3 \%$, phosphorus $0.3-1.4 \%$ and sodium $0.2-0.5 \%$, sodium oxide $1.85 \%$. According to [3], the ash has a $\mathrm{pH}$ of 10.48. In [3], the results of various sources are presented that substantiate the high content of carbon in wood ash in the range of

*Corresponding author: volkovsochi@gmail.com 
5-30\%, calcium (7-33\%), which depend on the type of wood and combustion temperature. In [4], a high content of calcium bicarbonates in the ash was 40-45 mg equivalent / $100 \mathrm{~g}$ of $\mathrm{Ca}^{2+}$.

Fluctuations of values are associated, according to [5] with tree varieties, soil-climatic features, and combustion temperature. So, in order to maintain the optimum soil $\mathrm{pH}$ level for the desired yield growth, the equivalent of calcium carbonate for different types of wood ash can vary in the range of $25-60 \%$. According to [6], a feature of the hornbeam investigated by us is the increased content of calcium in $\%$ per $100 \mathrm{~g}, \mathrm{CaCO}_{3}-17 \%, \mathrm{CaSiO}_{3}-16.5 \%, \mathrm{CaCl}_{2}$ - $12 \%, \mathrm{CaSO}_{4}-14 \%$. Thus, capillary wetting with an aggressive liquid medium was a negative effect on large-pore concrete. From [7] it is known that large-porous concrete (porosity $3-8 \%$, class B 12.5 - B 20) is characterized by a capillary mechanism of water transfer, which is taken into account when choosing the type and material of protection. According to the recommendations [8], Penetron penetrating waterproofing should not be used on extremely porous concrete, concrete with a very low cement content, while the numerical indicators of porosity and water-cement ratio are not specified. Studies with Penetron materials described in [9] made it possible to dwell on the choice of this protection as the object of study.

\section{Materials and Methods}

Damaged concrete cracks in the ceilings and columns of winter gardens were examined visually, using non-destructive testing methods, and taking core samples for laboratory tests of both strength and $\mathrm{pH}$ values of cement stone. Fresh core chips were dripped with a $1 \%$ alcohol solution of phenolphthalein, the color was identified with a $\mathrm{pH}$ scale. The data obtained were compared with the design and executive documentation, which allowed us to analyze the change in these characteristics of structures over 12 years. The entire period of operation of these structures took place with periodic moistening with an aqueous solution of ash, which serves as fertilizer for plants. In addition to the damaged concrete of the winter gardens, the $\mathrm{pH}$ of the concrete was measured for the structures of the same buildings, but not subjected to wetting with aqueous ash solutions.

Laboratory analysis of the seized ash was performed according to [10]. Soluble salts were recovered with water with a soil: water ratio of $1: 5$ with ion determination $\mathrm{CO}_{3}{ }^{2-}, \mathrm{HCO}_{3}{ }^{-}$, $\mathrm{Cl}{ }^{-}, \mathrm{Ca}^{2+}, \mathrm{Mg}^{2+}, \mathrm{Na}^{+}, \mathrm{K}^{+}, \mathrm{SO}_{4}{ }^{2-}$.

In our studies, the samples were in an air-dry state, crushed and passed through a sieve with round holes with a diameter of $2 \mathrm{~mm}$. A dispenser was used to add $150 \mathrm{ml}$ of distilled water with a dosing error of not more than $2 \%$. A soil sample weighing $30 \mathrm{~g}$ was weighed with an error of not more than $0.3 \mathrm{~g}$ and poured into a jar installed in a ten-position cassette. $150 \mathrm{ml}$ of freshly prepared distilled water were dosed to the weighed soil and mixed for 3 minutes. Then, the resulting suspension was filtered through a double pleated filter.

When determining ions $\mathrm{CO}_{3}^{2-}$ and $\mathrm{HCO}_{3}^{-}$(carbonate and bicarbonate alkalinity), the aqueous extract was sequentially titrated with a solution of sulfuric acid, first to $\mathrm{pH} 8.3$, and then to $\mathrm{pH}$ 4.4. according to the formulas:

- during titration to $\mathrm{pH} 8.3$, neutralization of the carbonate ion to the bicarbonate ion:

$$
\mathrm{CO}_{3}{ }^{2-}+\mathrm{H}^{+} \rightarrow \mathrm{HCO}_{3}{ }^{-}
$$

- during titration to $\mathrm{pH} 4,4$ neutralization of the bicarbonate ion:

$$
\mathrm{HCO}_{3}{ }^{-}+\mathrm{H}^{+} \rightarrow \mathrm{CO}_{2}+\mathrm{H}_{2} \mathrm{O}
$$

The visual establishment of equivalent points was used during titration with phenolphthalein ( $\mathrm{pH} \mathrm{8.3)} \mathrm{and} \mathrm{methyl} \mathrm{orange} \mathrm{(} \mathrm{pH} \mathrm{4.4).} \mathrm{To} \mathrm{a} 20 \mathrm{ml}$ extract, 1 drop of a $1 \%$ alcohol solution of phenolphthalein was added. When raspberry color appeared, the extract 
was titrated with $0.02 \mathrm{~N}$ sulfuric acid solution until the color of the indicator becomes discolored. Then, 1 drop of a $0.1 \%$ aqueous solution of methyl orange was added and titrated with $0.02 \mathrm{~N}$ sulfuric acid solution until the color changes from yellow to orange.

The study of the protective properties of penetrating waterproofing materials was obtained by determining the waterproof grade for concrete samples (cores) of class B concrete, grade 15 waterproof grade W 4, removed from greenhouse structures. The samples were penetrated by waterproofing Penetron materials and studied in laboratory conditions for installation for testing concrete for waterproofness UVB-MG4.01 by the method of "wet spot". The studies were carried out on six cylinder samples with a diameter of $15 \mathrm{~cm}$ with an average density of $2.34 \mathrm{~kg} / \mathrm{m}^{3}$. The results are presented in table 1.

\section{Results}

The results of determining the $\mathrm{pH}$ of the cement stone of the operated column structures showed $\mathrm{pH}=11.8-12.6$, overlap $\mathrm{pH}=9.2-9.4$. Concrete class of columns B 15-20, floors B $12.5-15$, concrete qualified as large-porous, porosity $7-8 \%$, containing basalt gravel with grain sizes up to $3 \mathrm{~cm}$, water-resistant grade W2-W4 (fig. 1).

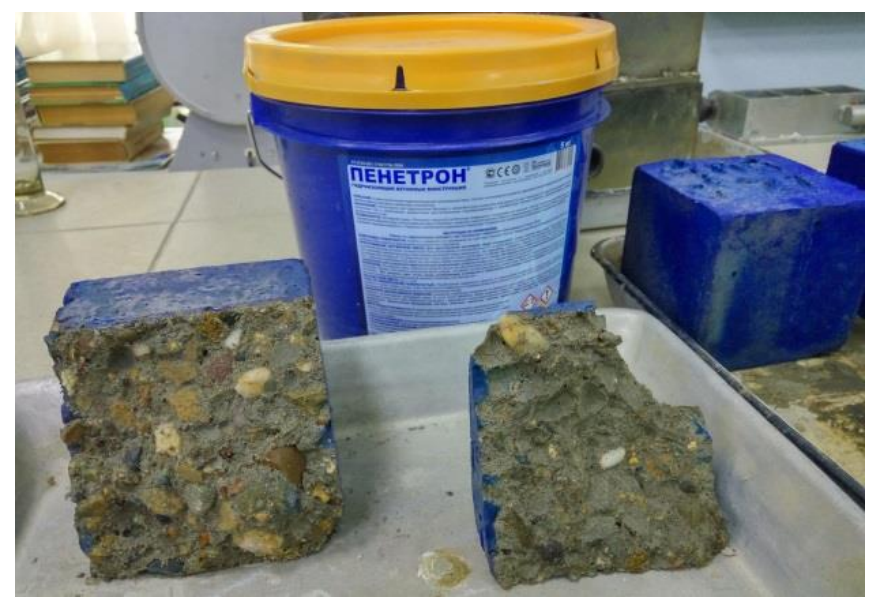

Fig. 1. Concrete qualified as large-porous, porosity $7-8 \%$.

The results of chemical analysis of the total alkalinity of the analyzed soil are calculated by summing the content of $\mathrm{CO}^{2-}{ }_{3}$ and $\mathrm{HCO}_{3}^{-}$, and amount to $1.62 \mathrm{mEq} / 100 \mathrm{~g}$ of soil. The water solution of ash during watering of plants has a bicarbonate alkalinity of $0.81 \mathrm{mEq} /$ $\mathrm{dm}^{3}$.

In accordance with Table B.3 [11], when the bicarbonate alkalinity of a liquid medium is from 0 to $1.05 \mathrm{mEq} / \mathrm{dm}^{3}$, it is slightly aggressive for concrete of waterproof grade W4 and below. According to [12], the total alkalinity of water is determined by anions of weak acids: $\mathrm{HCO}_{3}{ }^{-}, \mathrm{CO}_{3}{ }^{-}, \mathrm{H}_{2} \mathrm{SiO}_{3}$, assessment of water aggressiveness is given by the content of bicarbonate alkalinity $\mathrm{HCO}_{3}{ }^{-}$. within $0.7 \mathrm{mmol} / 1$ to $1.4 \mathrm{mmol} / \mathrm{l}$, which is consistent with our experimental data.

The results of determining the water resistance of concrete core samples with penetrating waterproofing protection by Penetron materials are presented in table 1 . It is noted that during the tests, water leakage was observed in samples 2 and 3, they showed the final brand for water resistance W 10. 
Table 1. Water resistance of concrete samples with penetrating waterproofing Penetron.

\begin{tabular}{|c|c|c|c|c|c|c|c|}
\hline 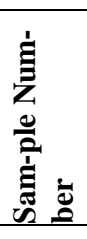 & 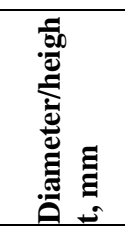 & है & 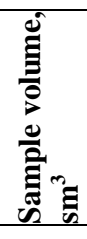 & 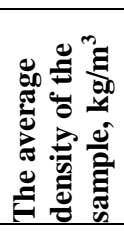 & 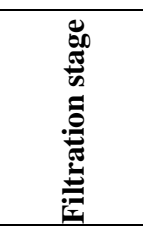 & 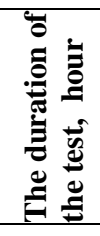 & 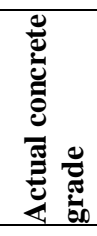 \\
\hline 1 & $150 / 149$ & 6062 & 2615 & 2318 & & & \multirow{6}{*}{ W 12} \\
\hline 2 & $150 / 150$ & 6082 & 2651 & 2294 & & & \\
\hline 3 & $150 / 150$ & 6099 & 2651 & 2300 & 6/1.2 MPa & $93: 12$ & \\
\hline 4 & $150 / 150$ & 6189 & 2615 & 2366 & 6/1.0 MPa & $82: 24$ & \\
\hline 5 & $150 / 149$ & 6131 & 2615 & 2344 & 7/1.4 MPa & 108:04 & \\
\hline 6 & $150 / 150$ & 6059 & 2651 & 2285 & & & \\
\hline
\end{tabular}

\section{Discussion}

Damage to concrete structures after 6-10 years after the start of operation caused by reactions of alkalis with silicas at $95 \%$ in conditions of high humidity, many researchers face, which is reflected in detail in [13]. It is noted that about $90 \%$ of alkalis can be contained in slag and fly ash in glassy phases, while it is difficult to estimate the amount of alkali passing into the liquid phase of concrete. A large aggregate - basalt containing interspersed plagioclase could also be reactive. At the same time, alkalis from the environment can damage porous concrete more significantly than alkalis of cement. Shrinkage cracks formed during alternate wetting and drying of concrete also had a negative effect. The structures under consideration are quite thin-walled; destruction is observed in the protective layers.

The obtained $\mathrm{pH}$ values of the cement stone of the investigated structures are certainly lower than the known average $\mathrm{pH}$ values of 13.5 and lower than the values determined at the construction stage, $\mathrm{pH}$ 12.6-12.8. In [13], processes with a $\mathrm{pH}$ of 13.6-10.9 are considered, the presence of disilicates is noted, which, at a $\mathrm{pH}$ below 10.9, turn into polysilicates. From [14] it is known bicarbonates $\left(\mathrm{NaHCO}_{3}\right)$ are used as setting accelerators in the preparation of concrete mixtures, but their influence already 28 days of age reduces the strength of concrete in tension and compression. The data [14] indicate that the initial strength of such mixtures on day 7 has increased characteristics, which is caused by the accelerated formation of ettringite and $\mathrm{CaCO}_{3}$ as a result of reactions. A further decrease in strength, according to [14], is due to the fact that $\mathrm{Na}^{+}$reduces adhesion between $\mathrm{C}-\mathrm{S}-\mathrm{H}$ gel by replacing $\mathrm{Ca}^{2+}$. It was shown that $\mathrm{NaHCO}_{3}$ solutions have a $\mathrm{pH}$ of 8.27 at a concentration of $1 \mathrm{mmol} / \mathrm{L}\left(25^{\circ} \mathrm{C}\right.$ and $1 \mathrm{~atm})$, and in [10] the value is refined to $\mathrm{pH} 10.4$. A comparison of $\mathrm{pH}$ values is presented in Fig. 2. 


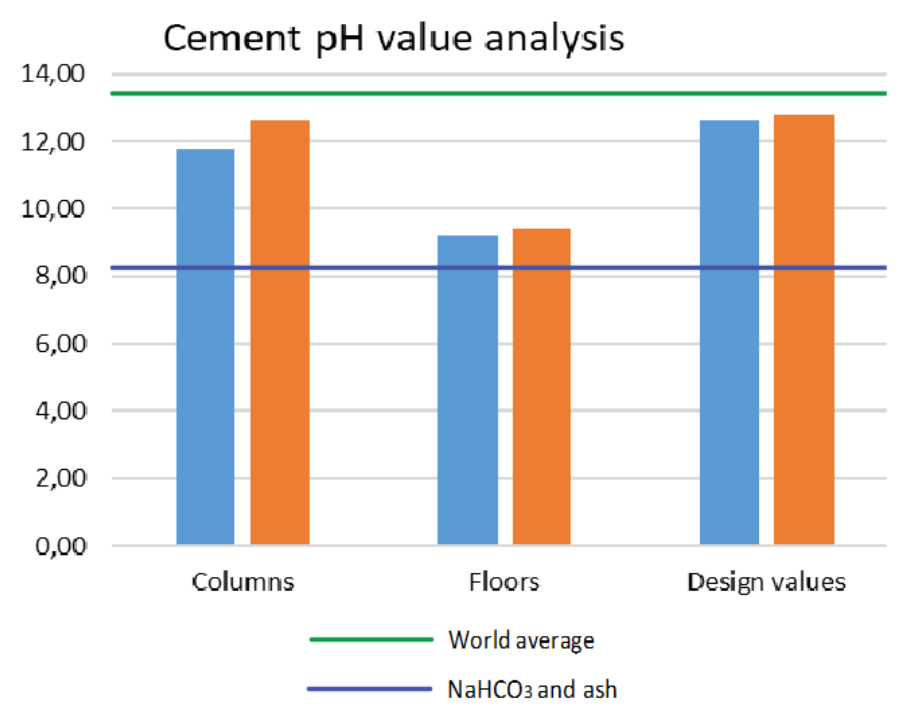

Fig. 2. Comparison of $\mathrm{pH}$ values.

Obviously, the project did not take into account such an operating environment, since in accordance with table D1 [11] concrete of class B 37 with a water resistance mark of W 8 should be used. As a measure of protection for concrete and reinforced concrete structures [16] in p. 14.1 and p. 14.2 it is recommended to carry out the treatment with penetrating formulations in order to increase the waterproofing ability and corrosion resistance, since during the Penetron treatment the destructive effect of the medium containing ash is not observed. Previously, in studies [17], penetration of waterproofing of Penetron compositions was evaluated by cleaving concrete samples of classes from B 7.5 to B 35, 21 days after application. It was shown that the white crystals of Penetron penetrating waterproofing completely filled the pore volume on the cleaved concrete samples of class B 12.5 to B 20, and protection was recognized as effective.

\section{Conclusions}

The obtained performance characteristics of columns and ceilings in winter gardens, the alkalinity of an aqueous ash solution, laboratory tests of Penetron penetrating waterproofing for large-porous concrete led to the following conclusions:

- The design class of concrete was reduced as B 20 structures of greenhouses and conservatories arranged on the attic floors of cottages in Sochi to values of B 12.5, concrete is porous and porous (porosity 3-8\%), waterproof grade W4.

- The reason for the reduction in the design class of concrete is caused by the prolonged action of an aqueous solution of hornbeam ash with a bicarbonate alkalinity of $0.81 \mathrm{mEq} / \mathrm{dm}^{3}$, which is slightly aggressive for concrete with the indicated characteristics.

- Experimentally selected and recommended protection of such structures with Penetron penetrating waterproofing, which increases the waterproof rating to $\mathrm{W} 10$.

\section{References}

1. L. Parfenova, Vestnik Of PSU J. 16, 68-72 (2013)

2. V.M. Klechkovskij, A.V. Peterburgskij, Agrohimija (Kolos, Moskva, 1967)

3. A.C. Twort, D.D. Ratnayaka, M.J. Brandt, Twort's Water Supply, $5^{\text {th }}$ ed. (2006) 
4. K.S. Kazeev, G.V. Mokrikov, J.V. Akimenko, M.A. Mjasnikov, S.I. Kolesnikov, Ekologicheskaya ocenka primeneniya tehnologii No-Till v Rostovskoy oblasti (JFU, Rostov-na-Donu, 2018)

5. S. Chowdhury, M. Mishra, O. Suganya, Ain Shams Engineering Journal 6, 429-437 (2015)

6. V.G. Scherbina, Y.G. Scherbina, A.N. Volkov, Innov. Sys. 1, 12-30 (2014)

7. L.I. Dvorkin, O.L. Dvorkin, Osnovy betonovedeniya (Sankt-Petersburg, Stroy-Beton, 2006)

8. Tehnologicheskij reglament na vypolnenie rabot po gidroizoljacii $i$ antikorrozionnoj zashhite monolitnyh i sbornyh betonnyh i zhelezobetonnyh konstrukcij (Moskva, SRO "RSPPG", 2017)

9. A.A. Kakosyan, E.E. Yurchenko, A.N. Volkov, Integration, partnership and innovations in construction science and education (IPICSE-2018), 82-85 (2018) http://mgsu.ru/resources/izdatelskaya-deyatelnost/izdaniya/izdaniya-otkrdostupa/2018/IPICSE-2018.pdf

10. Soil. Procedures (methods) of analysis of composition and properties of soil samples. General requirements for development (2014)

11. SP 28.13330.2017. Protection against corrosion of construction (2017)

12. P.A. Fonarjov, Inzhenerno-geotehnicheskie izyskanija $v$ transportnom stroitelstve (Moscow, MADI, 2016)

13. N.K. Rozental, A.N. Rozental, G.V. Ljubarskaja, Beton i zhelezobeton 1, 50-60 (2012)

14. Y. Wang, F. He, J. Wang, Q. Hu, Materials (Basel, 2019)

15. J.B.J. Van Ryssen, Appl. Anim. Husb. Rural Develop. 11, 62-67 (2018)

16. SP 72.13330.2016. Protection of buildings, facilities and structures against corrosion (2019) 